Esta publicación cientifica en formato digital es continuidad de la revista impresa ISSN-Versión Impresa 0798-1406 / ISSN-Versión on line 2542-3185Depósito legal pp
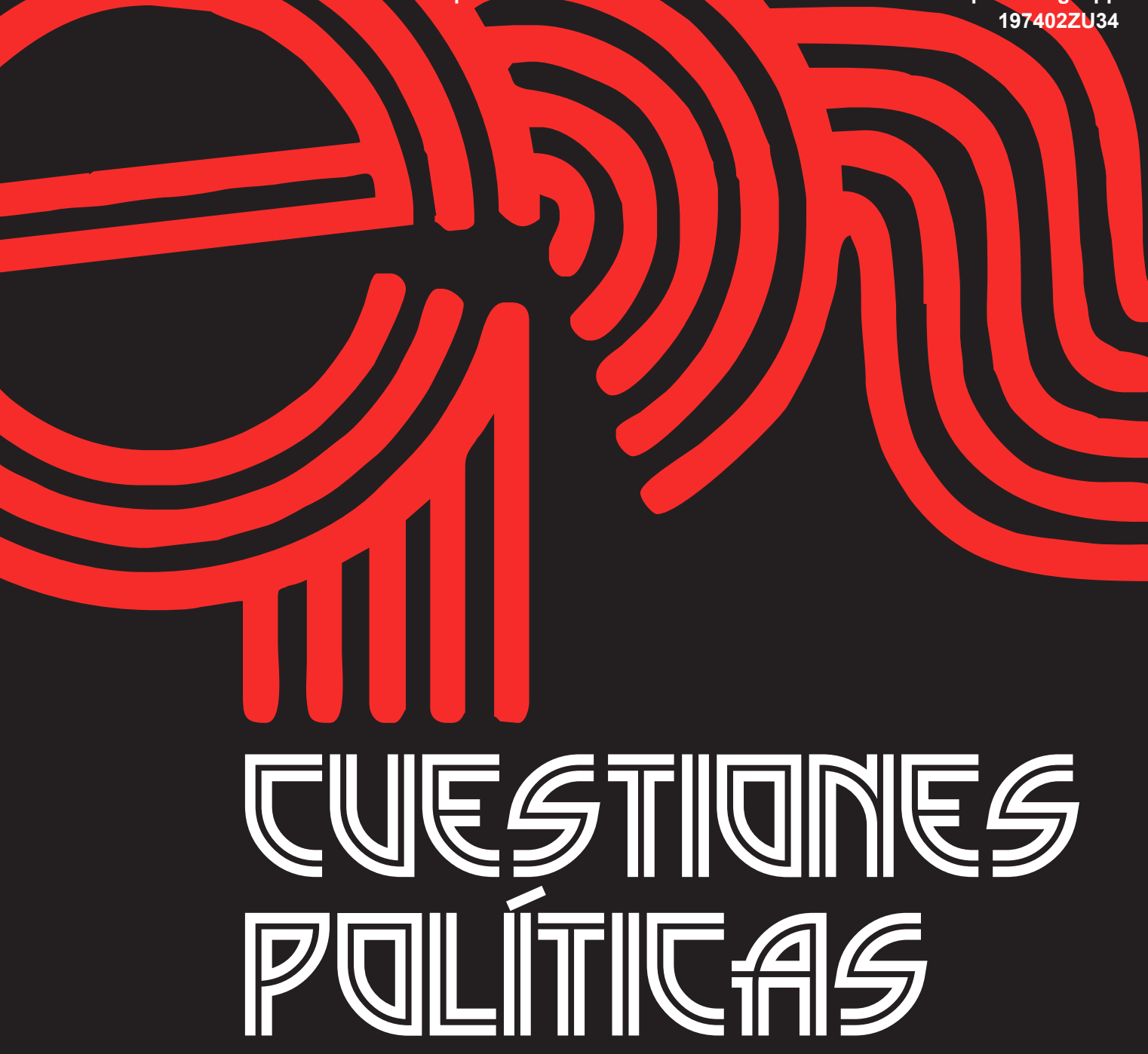

Instituto de Estudios Políticos y Derecho Público "Dr. Humberto J. La Roche" de la Facultad de Ciencias Jurídicas y Políticas de la Universidad del Zulia Maracaibo, Venezuela
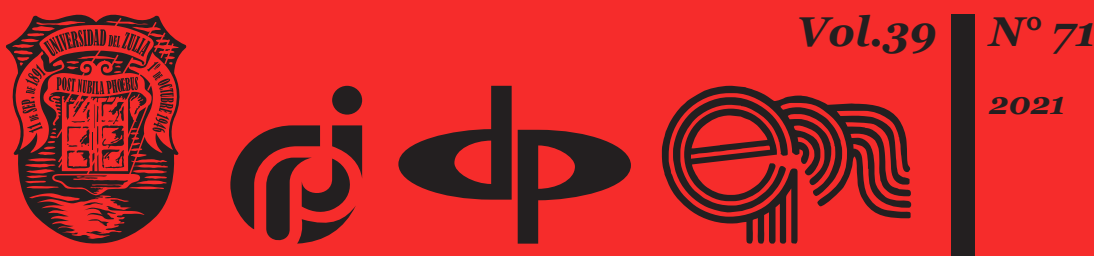


\title{
Natural population movement and COVID-19: data from Russia
}

\author{
DOI: https://doi.org/10.46398/cuestpol.3971.60
}

\author{
Ilmir Nusratullin * \\ Igor Drozdov ** \\ Alexei Ermakov *** \\ Elena Koksharova **** \\ Maya Mashchenko $* * * * *$
}

\begin{abstract}
The COVID-19 pandemic is highly infectious, so it paralyzed the health systems of many countries causing a high mortality rate. Official data on COVID-19 deaths at many sites are questioned, and the figures are considered several times higher than official data. In this sense, the objective of the study was to determine the impact of the COVID-19 pandemic on the natural movement of the population and, in addition, to evaluate the real mortality rate from COVID-19 in Russia from the construction of predictive mortality models. The study used data from the World Health Organization and the Statistical Service of the Federal State of Russia; se used linear and polynomial models to construct mortality models. The study revealed an underestimation of the official COVID-19 death rate by 2.4 to 6.8 times, depending on the data source. There was a sharp increase in mortality in Russia in 2020 among people over 50 years of age, and with the increase in age, mortality increased. The main reasons for the sharp increase in mortality were coronary heart disease, cerebrovascular diseases, and
\end{abstract} respiratory diseases, among others.

Keywords: COVID-19 pandemic; demographics; vital movement; mortality, geopolitics.

* PhD in Economics, Associate Professor, Bashkir State University, Ufa, Russia. ORCID ID: https:// orcid.org/oooo-0001-7810-2945

** PhD in Psychology, Associate Professor, Far Eastern Federal University, Vladivostok, Russia. ORCID ID: https://orcid.org/oooo-ooo1-7311-4920

*** PhD in Pedagogy, Associate Professor, Russian State University of Physical Education, Sport, Youth and Tourism (SCOLIPE), Moscow, Russia. ORCID ID: https://orcid.org/oooo-0002-7505-085X

**** PhD in Pedagogy, Associate Professor, Russian State Vocational Pedagogical University, Yekaterinburg, Russia. ORCID ID: https://orcid.org/oooo-0003-4956-5291

***** PhD in Pedagogy, Associate Professor, Russian State Vocational Pedagogical University, Yekaterinburg, Russia. ORCID ID: https://orcid.org/oooo-0002-7071-6376

Recibido el 01/09/2021 Aceptado el 22/11/2021 


\section{Movimiento de población natural y COVID-19: datos de Rusia}

\section{Resumen}

La pandemia de COVID-19 es altamente infecciosa, por lo que paralizó los sistemas de salud de muchos países provocando una alta tasa de mortalidad. Se cuestionan los datos oficiales sobre muertes por COVID-19 en muchos sitios, y las cifras se consideran varias veces más altas que los datos oficiales. En este sentido, el objetivo del estudio fue determinar el impacto de la pandemia de COVID-19 en el movimiento natural de la población y, además, evaluar la tasa de mortalidad real por COVID-19 en Rusia a partir de la construcción de modelos predictivos de mortalidad. El estudio utilizó datos de la Organización Mundial de la Salud y del Servicio de Estadísticas del Estado Federal de Rusia; se utilizaron modelos lineales y polinomiales para construir modelos de mortalidad. El estudio reveló una subestimación de la tasa oficial de mortalidad por COVID-19 de 2,4 a 6,8 veces, según la fuente de datos. Se produjo un fuerte aumento de la mortalidad en Rusia en 2020 entre las personas mayores de 50 años y, con el aumento de la edad, la mortalidad aumentó. Las principales razones del fuerte aumento de la mortalidad fueron las cardiopatías coronarias, las enfermedades cerebrovasculares y las enfermedades respiratorias, entre otras.

Palabras clave: Pandemia COVID-19; demografía; movimiento vital; mortalidad, geopolítica.

\section{Introduction}

In December 2019, the world learned about the emergence of COVID-19, a new infectious disease, or Severe Acute Respiratory Syndrome Coronavirus 2 (SARS-CoV-2) (Huang et al., 2020). The epidemic that began in December 2019 has now spread to all continents and countries of the world. As of July 15, 2021, there were 188,128,952 confirmed cases of COVID-19, including 4,059,339 deaths (World Health Organization, 2021). The mortality rate from COVID-19 is different in different countries, and there are countries with a high mortality rate (for example, Peru - 590.22 deaths per 100.000 population, Hungary - 307.21, Bosnia and Herzegovina -294.56), as well as with a low mortality rate (for example, Tanzania - 0.04 deaths per 100.000 population, Lao - 0.04, Burundi - 0.07) (World Health Organization, 2021).

Today, some countries have managed to cope with cases of the disease with a high degree of recovery, and they have developed sustainable 
methods of treatment (Are and Ekum, 2020). At the end of 2020 and at the beginning of 2021, vaccines against COVID-19 were developed, which are now being actively used for vaccination all over the world. As of July 15, 2021, 3,402,275,866 doses of vaccine have been given (World Health Organization, 2021). New coronavirus strains are of particular concern today (Bollinger and Ray, 2021), however, at the moment they do not fundamentally affect the overall strategy for overcoming the crisis caused by the pandemic.

The COVID-19 pandemic has had a great impact on public relations, the economy, and the financial system of the countries of the world (Nusratullin et al., 2021). However, the most negative consequence of the pandemic is an increase in the death rate of the population. The increase in mortality was not only due to the disease itself, but due to the lack of bed capacity, equipment, insufficient financing of the health care system, and inability to provide planned medical care in the existing situation. (Gerli et al., 2020). The pandemic also had a negative impact on the birth rate, as due to stress in 2020, there was a decrease in marriage and birth rates. In addition, the closure of borders and tightening of the rules for crossing them led to a decrease in migration (Ryazantsev et al., 2021).

If we talk about mortality from COVID-19 in Russia, then the official data are as follows. In Russian Federation, from 3 January 2020 to 15 July 2021, there have been 5882295 confirmed cases of COVID-19 with 146069 deaths. As of 12 July 2021, a total of 47572228 vaccine doses have been administered (World Health Organization, 2021). These data indicate that the COVID-19 pandemic has greatly affected the demographic situation in Russia.

However, it should be noted that the official data on deaths from COVID-19 cannot explain the real numbers of depopulation. The natural population decline within the year in Russia in 2020 increased by 2.2 times compared to 2019 and amounted to 702,072 people, which is $0.5 \%$ of the population of all of Russia (Federal State Statistics Service of Russia, 2021). In this regard, the problem of determining the true impact of the COVID-19 pandemic on mortality in Russia has become topical.

It is quite difficult to assess the direct impact of coronavirus on mortality in a particular country since different countries apply different standards for the causes of death partition (Middelburg and Rosendaal, 2020). In this study, we will assess mortality from COVID-19 by constructing predictive mortality models based on data for 2011-2019 and forecasting for 2020 within the established trend. And then we will compare the results obtained and the official data on mortality from COVID-19.

The purpose of this study is to determine the impact of the COVID-19 pandemic on the natural population movement and to assess the real 
mortality from COVID-19 in Russia based on the construction of predictive mortality models. To achieve this goal, it is necessary to solve the following tasks:

1) To analysed data on the natural population movement in Russia.

2) To build predictive models of mortality in Russia as a whole and for causes of death in particular.

3) to compare the results obtained with official data and draw conclusions.

\section{Literature Review}

With the spread of COVID-19 since the end of 2019, the first studies have focused primarily on the spread and dynamics of the spread of the virus. The main epidemiological, clinical and laboratory characteristics of COVID-19 disease, as well as treatment data and clinical outcomes of patients, are disclosed in the work of Huang et al. (2020), Liu et al. (2020), Ferguson et al. (2020).

The first predictions of the spread of the new coronavirus were made in the studies of Read et al. (2020), Zhao et al. (2020), Li et al., (2020), and in addition, they draw attention to the seriousness of the problem of the rapid spread of COVID-19. The first assessment of the impact of the new epidemic on the health systems of countries was carried out in the works of Tang et al. (2020), Yang et al. (2020).

Further research was aimed at finding ways to reduce the incidence of new COVID-19 cases, as well as the causes of asymptomatic cases. A study by Wu and McGoogan (2020) and Oran and Topol (2020) confirmed that people with asymptomatic COVID-19 disease are carriers of the disease and can actively infect people around them. Adeniyi et al. (2020) confirm that compliance with hygiene rules and rules of conduct in the conditions of the spread of infectious diseases reduces the rate of spread of a new coronavirus infection.

Today, there are many studies on the consequences of the COVID-19 epidemic on various areas of human activity. For example, the United Nations (2020) report shows that in 2020, the world gross domestic product declined by an estimated $4.3 \%$, and in developed countries, it dropped by $5.6 \%$. 420 million jobs were lost in the last two quarters of 2020. This is considerably superior to the global recession in 2009, when production went down by only $1.7 \%$.

The economic impact of COVID-19 is assessed by Chudik et al. (2020). The results of the analysis show that the global recession will be prolonged 
Ilmir Nusratullin, Igor Drozdov, Alexei Ermakov, Elena Koksharova y Maya Mashchenko
990 Natural population movement and COVID-19: data from Russia

and no country will escape its consequences, regardless of the strategies to mitigate the consequences of COVID-19. Iluno et al. (2021) found that there is a non-linear relationship between mortality from COVID-19 and economic well-being, with mortality from COVID-19 negatively affecting well-being.

You can also highlight a separate block of research related to the interpretation, analysis and modelling of data on mortality from COVID-19. In their study, Sornette et al. (2020) have analysed the statistics of mortality from the epidemic of a new coronavirus infection in a number of countries. According to the data obtained, it has been revealed that the highest mortality rate per million inhabitants is observed in Western countries. The main reason for the relatively more severe COVID-19 epidemic in Western countries is the large number of older people, with the exception of Norway and Japan where other factors predominate.

Ivanaj and Oukhallou (2020) have analysed the economic and institutional determinants of COVID-19 mortality in their study. As a result, it was found that economic variables do not have a direct impact on COVID-19 mortality, while institutional variables such as the quality of regulation, government effectiveness and control of corruption, etc. have a significant and consistent downward correlation with COVID-19 mortality in different countries. These results support the claim that investing in institutions enhancing helps reduce mortality from infectious diseases.

Analyzing the scientific works of Aronov et al. (2020), Drapkina et al. (2020), Ferraro et al. (2020) regarding the modelling of COVID-19 morbidity and mortality from it, we should note that preliminary prognoses regarding official data are overestimated. This could be due to the more efficient operation of the health care system, or due to the underestimation of the official death rate from COVID-19. Further research has shown that the second reason is much more common.

Gerli et al. (2020) have assessed the spread of the COVID-19 virus, described its trends in the 27 countries of the European Union, Switzerland, and Italy, and have made predictions of mortality from it. Shojaee et al. (2020) have estimated the number of deaths in Italy, Iran and South Korea from COVID-19. Al-Raeei (2020) has calculated the COVID-19 pandemic mortality rates for China, the United States, Russia, and the Syrian Arab Republic. Sebastiani et al. (2020), Chintalapudi et al. (2020), Onder et al. (2020) have done a great job assessing the spread of the new coronavirus, described the trends in the spread of Covid-19 in Italy and have made the first mortality prognoses from it. Anastassopoulou et al. (2020) и Gao et al. (2020) have built the first projections of the number of deaths from COVID-19 in China. Sánchez-Villegas and Daponte Codina (2020) have studied the COVID-19 epidemic and gave mortality prognoses in Spain. Semenova et al. (2020) have predicted the number of deaths from COVID-19 
in Kazakhstan. Vandoros (2020) has studied the impact of COVID-19 on mortality in England and Wales.

As part of this study, we will build predictive models of mortality in Russia as a whole and then compare them with actual data for their reasons and draw conclusions about the true scale of mortality from COVID-19.

\section{Methodology}

The study used data from the World Health Organization, 2021 and the Federal State Statistics Service of Russia, 2021 for 2011-2020. The work used data on the number of deaths, births, data on the natural movement of the population, fertility and mortality rates including by age groups, data on causes of death, and data on life expectancy.

To build a mortality model for Russia as a whole, a polynomial model of the second degree was used. Let $\mathrm{y}$ be the dependent variable and $\mathrm{x}$ the independent variable, polynomial regression is a special case of multiple regression with one independent variable $\mathrm{x}$. A one-parameter polynomial regression model with the $\mathrm{k}$ order can be expressed as:

$$
\mathrm{y}_{\mathrm{i}}=\beta_{0}+\beta_{1} \mathrm{x}_{\mathrm{i}}+\beta_{2} \mathrm{x}_{\mathrm{i}}^{2}+\cdots+\beta_{\mathrm{k}} \mathrm{x}_{\mathrm{i}} \mathrm{k}+\mathrm{e}_{\mathrm{i}}, \mathrm{i}=1,2, \cdots, \mathrm{n} \text {; }
$$

where $k$ is the order of the polynomial, the $\beta$ s are the unknown parameters to be estimated, and $e$ is the error term.

If $k=1$, then equation (1) becomes:

$\mathrm{y}_{\mathrm{i}}=\beta_{0}+\beta_{1} \mathrm{x}_{\mathrm{i}}+\mathrm{e}_{\mathrm{i}} ; \mathrm{i}=1,2, \cdots, \mathrm{n}$.

Equation (2) is a simple linear model.

If $k=2$, then equation (1) becomes:

$\mathrm{y}_{\mathrm{i}}=\beta_{0}+\beta_{1} \mathrm{x}_{\mathrm{i}}+\beta_{2} \mathrm{x}_{\mathrm{i}}^{2}+\mathrm{e}_{\mathrm{i}} ; \mathrm{i}=1,2, \cdots, \mathrm{n}$. 
To build models of mortality due to their causes, a polynomial model of the first degree, or simply a linear model, was used (2). The choice of models for making a prognosis was carried out in the framework of their reliability.

\section{Results and Discussion}

Analysing the natural movement of the population in Russia over the past 10 years, it should be noted that it has a negative trend and can be characterised as depopulation. In society, the institution of the family is being transformed and value attitudes towards children are changing, women begin to give birth to fewer children and do it much later (Ryazantsev et al., 2021). In Russia, simple reproduction of the population is not ensured (2.14-2.15 children per woman of the reproductive age). The total fertility rate in Russia from 2011 to 2020 is shown in Figure 1.

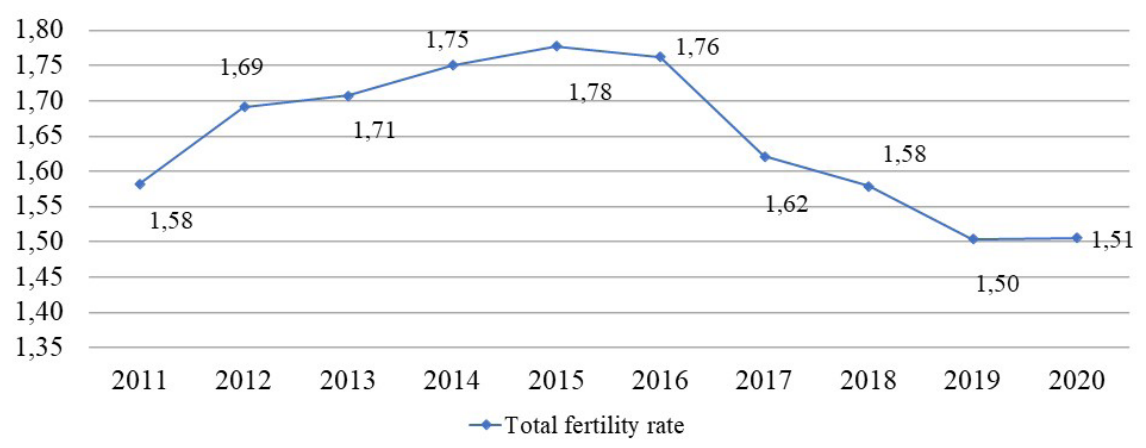

Figure 1. Total fertility rate in Russia from 2011 to 2020

Source: Federal State Statistics Service of Russia, 2021.

The total fertility rate in Russia from 2011 to 2015 grew steadily from 1.58 to 1.78 , but since 2016 it has seen a sharp drop to 1.51 in 2020. The decline in the birth rate also affects the natural movement of the population in Russia. But in 2020, a new factor is added to the negative trend of declining fertility, the COVID-19 pandemic. Table 1 shows data on the number of deaths and births in Russia over the past 10 years. 
Table 1. The number of births, deaths and natural increase in Russia for the period of 2011-2020

\begin{tabular}{|l|l|l|l|l|l|}
\hline & $\mathbf{2 0 1 1}$ & $\mathbf{2 0 1 2}$ & $\mathbf{2 0 1 3}$ & $\mathbf{2 0 1 4}$ & $\mathbf{2 0 1 5}$ \\
\hline $\begin{array}{l}\text { Number of births within } \\
\text { a year }\end{array}$ & 1796629 & 1902084 & 1895822 & 1942683 & 1940579 \\
$\begin{array}{l}\text { Number of deaths within } \\
\text { a year } \\
\begin{array}{l}\text { Natural increase within a } \\
\text { year }\end{array}\end{array}$ & 1925720 & 1906335 & 1871809 & 1912347 & 1908541 \\
\cline { 2 - 7 } & -129091 & -4251 & 24013 & 30336 & 32038 \\
\hline $\begin{array}{l}\text { Number of births within } \\
\text { a year }\end{array}$ & 2016 & 2017 & 2018 & 2019 & 2020 \\
\hline $\begin{array}{l}\text { Number of deaths within } \\
\text { a year }\end{array}$ & 1888729 & 1690307 & 1604344 & 1481074 & 1436514 \\
\hline $\begin{array}{l}\text { Natural increase within a } \\
\text { year }\end{array}$ & -2286 & -135818 & -224566 & -317233 & -702072 \\
\hline
\end{tabular}

Source: Federal State Statistics Service of Russia, 2021.

Table 1 clearly shows that from 2011 to 2015, there is a clear trend towards an increase in the number of births from 1.80 million to 1.94 million, but in 2016 this trend was reversed and in 2020 the number of births was 1.44 million. As for the number of deaths, its trend is clearer and there is a gradual decrease in mortality from 1.93 million to 1.80 million, but only in 2020, there is a sharp jump to 2.14 million. These trends can be traced more clearly in Figure 2.

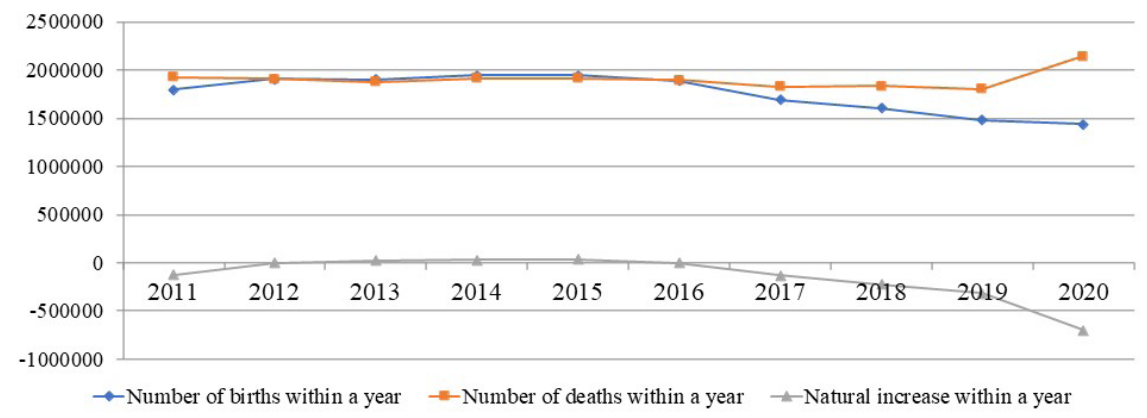

Figure 2. The number of births, deaths and natural increase in Russia for the period of 2011-2020

Source: Federal State Statistics Service of Russia, 2021 
The presented dynamics of fertility and mortality in Russia led to the fact that positive population growth in 2013-2015 was replaced by negative population growth since 2016 and sharply increased in 2020 and amounted to a natural population decline of 0.7 million people in a year.

The decline in the number of births has a long-term trend that has been observed since 2016. The decrease in the total number of births is mainly explained by the decrease in the number of women giving birth at an early age (15-24 years) and mean age of childbearing (from 25-34 years). It should be noted that in recent years there has been an established trend in the number of women giving birth at the age of 35 and older (Table 2, Figure 3).

Table 2. Age-specific fertility rates (the average number of births per 1000 women aged per year, years)

\begin{tabular}{|c|c|c|c|c|c|c|c|c|c|c|}
\hline & $\mathbf{2 0 1 1}$ & $\mathbf{2 0 1 2}$ & $\mathbf{2 0 1 3}$ & $\mathbf{2 0 1 4}$ & $\mathbf{2 0 1 5}$ & $\mathbf{2 0 1 6}$ & $\mathbf{2 0 1 7}$ & $\mathbf{2 0 1 8}$ & $\mathbf{2 0 1 9}$ & $\mathbf{2 0 2 0}$ \\
\hline 15-19 years & 26.70 & 27.30 & 26.60 & 26 & 24 & 21.50 & 18.39 & 16.10 & 14.60 & 14.10 \\
\hline 20-24 years & 87.50 & 91.30 & 89.90 & 89.80 & 90 & 87.20 & 81.20 & 78.40 & 74.80 & 73.59 \\
\hline 25-29 years & 99.80 & 106.60 & 107.60 & 110.20 & 112.60 & 111.50 & 100.10 & 96.50 & 91.20 & 92.60 \\
\hline 30-34 years & 68.20 & 74.30 & 76.20 & 79.80 & 83 & 84.40 & 77.20 & 76.09 & 71.59 & 70.80 \\
\hline 35-39 years & 31.40 & 34.90 & 36.79 & 39 & 39.79 & 41 & 39.20 & 39.70 & 38.70 & 39.20 \\
\hline 40-44 years & 6.30 & 7 & 7.40 & 8.10 & 8.30 & 8.80 & 8.69 & 8.90 & 8.90 & 9.19 \\
\hline 45-49 years & 0.30 & 0.30 & 0.30 & 0.40 & 0.40 & 0.50 & 0.50 & 0.50 & 0.50 & 0.60 \\
\hline 50-54 years & o & o & o & o & o & o & 0 & 0 & 0.10 & 0.10 \\
\hline
\end{tabular}

Table 2 and Figure 3 show the demographic problem of the Russian society, when women are giving birth less and less, and the number of children in families is decreasing, of which there are mainly 1-2, rarely 3 or more. The decline in the number of births from year to year in Russia is a long-term trend and is more associated with economic problems (Nusratullin et al., 2020), with changes in society and the psychology of people. 


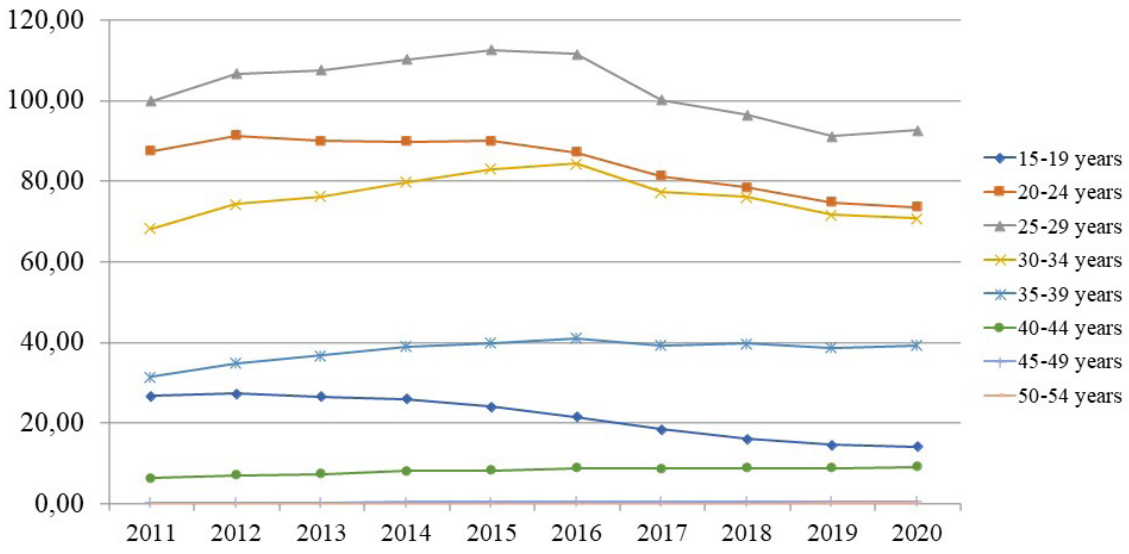

Figure 3. Age-specific fertility rates (the average number of births per 1000 women aged per year, years)

Source: Federal State Statistics Service of Russia, 2021

However, as mentioned above, the increase in mortality in 2020 to 2.13 million people compared with 1.79 million people in 2019 is not a consequence of the current trend, but it is more associated with the COVID-19 factor. But if we turn to official statistics, in 2020, 59,019 people died from COVID-19 in Russia (Starostina and Tkachev, 2021). This suggests a conclusion either about the presence of another factor in the increase in mortality, or about the underestimation of official data on mortality from the pandemic.

To answer this question, let us first find the number of "excess deaths" in 2020, and for this we will build a predictive mortality model based on data for 2011-2019. To build the trend line of the time series, the following models were tested: exponential, linear, logarithmic, and polynomial. The resulting models and the degree of their reliability are presented in Table 3 .

\section{Table 3. Mortality models in Russia and the degree of their reliability}

\begin{tabular}{|c|c|c|}
\hline Model type & Model & $\begin{array}{c}\text { Degree of the reli- } \\
\text { ability, } \mathrm{R}^{2}\end{array}$ \\
\hline Exponential & $\mathrm{y}=9224452819288.89 \mathrm{e}^{-0.01 x}$ & $\mathrm{R}^{2}=0.73$ \\
\hline Linear & $\mathrm{y}=-14243.78 \mathrm{x}+30575568.86$ & $\mathrm{R}^{2}=0.73$ \\
\hline
\end{tabular}


Ilmir Nusratullin, Igor Drozdov, Alexei Ermakov, Elena Koksharova y Maya Mashchenko

\begin{tabular}{|c|c|c|}
\hline Logarithmic & $\mathrm{y}=-28695655.05 \ln (\mathrm{x})+220201611.33$ & $\mathrm{R}^{2}=0.73$ \\
\hline $\begin{array}{c}\text { Second-order } \\
\text { polynomial }\end{array}$ & $\mathrm{y}=-17655.77 \mathrm{x}^{2}+71109098.34 \mathrm{x}-71596$ & $\mathrm{R}^{2}=0.96$ \\
\hline
\end{tabular}

Source: calculated by the authors.

As can be seen from the table, the most reliable mortality model in Russia is polynomial. We will build it and predict mortality in Russia in 2020 according to the data of 2011-2019.

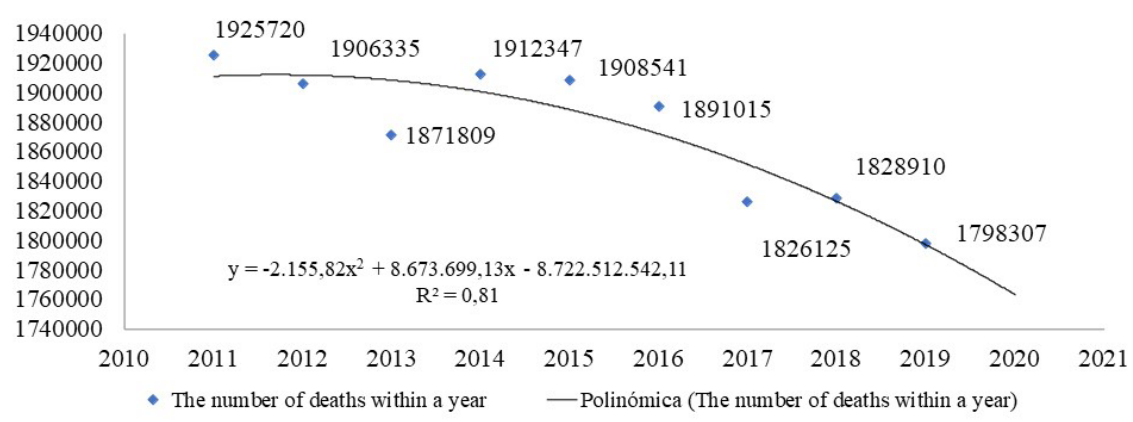

\section{Figure 4. Polynomial mortality model in Russia according to 2011-2019 data}

Source: calculated by the authors.

According to the model obtained, the number of deaths in 2020 was expected in the amount of $1,751,773$ deaths, but according to the actual data, the number of deaths in Russia was $2,138,586$ deaths. That is, the number of excess deaths in Russia was 386,813 deaths. These figures are in no way combined with the data on the number of deaths from COVID-19 which according to official data in 2020 amounted to 57,019 (Starostina and Tkachev, 2021). To clarify the reasons for the sharp increase in mortality, let us further consider the age at which the increase in mortality occurred and their causes.

Age-specific death rates are calculated as the ratio of the deceased people of the corresponding sex and age during the calendar time to the average annual number of people of this age per 1000 people. This indicator shows how often people of a certain age die. Usually, the older the population group, the higher the mortality rate. Let `s consider this indicator in Table 4 and Figure 5 . 
Table 4. Age-specific death rates

\begin{tabular}{|c|c|c|c|c|c|c|c|c|c|c|}
\hline & 2011 & 2012 & 2013 & 2014 & 2015 & 2016 & 2017 & 2018 & 2019 & 2020 \\
\hline 1-4 years & 0.50 & 0.50 & 0.40 & 0.40 & 0.40 & 0.40 & 0.30 & 0.30 & 0.30 & 0.30 \\
\hline 5-9 years & 0.30 & 0.30 & 0.20 & 0.20 & 0.20 & 0.20 & 0.20 & 0.20 & 0.20 & 0.20 \\
\hline $\begin{array}{l}10-14 \\
\text { years }\end{array}$ & 0.30 & 0.30 & 0.30 & 0.30 & 0.30 & 0.30 & 0.30 & 0.20 & 0.20 & 0.20 \\
\hline $\begin{array}{l}15-19 \\
\text { years }\end{array}$ & 0.80 & 0.80 & 0.80 & 0.80 & 0.70 & 0.70 & 0.60 & 0.60 & 0.60 & 0.60 \\
\hline $\begin{array}{l}20-24 \\
\text { years }\end{array}$ & 1.60 & 1.50 & 1.50 & 1.40 & 1.30 & 1.10 & 1 & 1 & 0.90 & 1 \\
\hline $\begin{array}{l}25-29 \\
\text { years }\end{array}$ & 2.70 & 2.50 & 2.40 & 2.29 & 2 & 1.80 & 1.60 & 1.50 & 1.40 & 1.40 \\
\hline $\begin{array}{l}30-34 \\
\text { years }\end{array}$ & 4.09 & 4 & 3.90 & 3.70 & 3.40 & 3.10 & 2.70 & 2.50 & 2.40 & 2.50 \\
\hline $\begin{array}{l}35-39 \\
\text { years }\end{array}$ & 4.90 & 4.80 & 4.80 & 5 & 4.80 & 4.50 & 4.09 & 4 & 3.80 & 4 \\
\hline $\begin{array}{l}40-44 \\
\text { years }\end{array}$ & 5.90 & 5.60 & 5.60 & 5.70 & 5.70 & $5 \cdot 50$ & 5.09 & 5.20 & 5.20 & 5.70 \\
\hline $\begin{array}{l}45-49 \\
\text { years }\end{array}$ & 8 & $7 \cdot 50$ & $7 \cdot 30$ & $7 \cdot 30$ & 7.10 & 6.80 & 6.30 & 6.40 & 6.40 & 7.30 \\
\hline $\begin{array}{l}50-54 \\
\text { years }\end{array}$ & 10.90 & 10.30 & 9.90 & 9.80 & 9.60 & 9.40 & 8.60 & 8.69 & 8.50 & 9.69 \\
\hline $\begin{array}{l}55-59 \\
\text { years } \\
\end{array}$ & $15 \cdot 5^{0}$ & 14.70 & 14 & 13.90 & 13.50 & 13.20 & 12.40 & 12.30 & 12.10 & 13.90 \\
\hline $\begin{array}{l}60-64 \\
\text { years }\end{array}$ & 21.80 & 20.80 & 20.10 & 19.80 & 19.50 & 19.10 & 18 & 18 & 17.60 & 20.60 \\
\hline $\begin{array}{l}65-69 \\
\text { years } \\
\end{array}$ & 28.60 & 27 & 26 & 26.20 & 26.20 & 26.40 & 25.10 & $25 \cdot 30$ & 24.40 & 29.60 \\
\hline $\begin{array}{l}70-74 \\
\text { years } \\
\end{array}$ & 41.50 & 41.20 & 40.10 & 39.10 & 38.40 & 36.70 & 34.29 & 34 & 34.10 & 42.60 \\
\hline $\begin{array}{l}75-79 \\
\text { years }\end{array}$ & 64.40 & 61.80 & 58.40 & 58.20 & 58 & 57.10 & 56 & $55 \cdot 70$ & 53.40 & 64 \\
\hline $\begin{array}{c}80-84 \\
\text { years }\end{array}$ & 102 & 101.70 & 98.90 & 96.70 & 95.20 & 92.20 & 87.10 & 84 & 82.70 & 100.70 \\
\hline $\begin{array}{c}85 \text { years } \\
\text { older }\end{array}$ & 174.40 & 173.70 & 171.80 & 171.50 & 172.50 & 171.20 & 168.90 & 168.50 & 163.69 & 190.20 \\
\hline
\end{tabular}

Source: Federal State Statistics Service of Russia, 2021.

As can be seen from the table and the figure, the greatest increase in mortality by age group occurred among the population over 50, and the older is the age group, the higher the rate of increase in mortality is. In the population aged 41 to 49 , the mortality rate increased insignificantly, but in the population under the age of 41 , it practically did not change. 
Ilmir Nusratullin, Igor Drozdov, Alexei Ermakov, Elena Koksharova y Maya Mashchenko

998

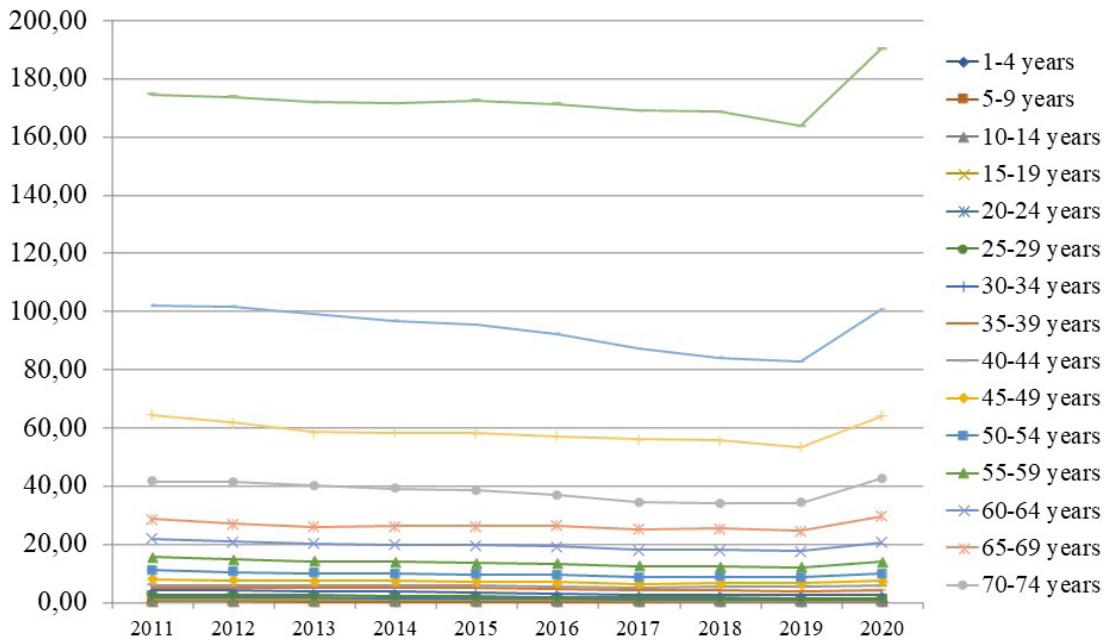

Figure 5. Age-specific death rates

Source: Federal State Statistics Service of Russia, 2021.

Mortality data by age group indirectly suggests that their causes are associated with the COVID-19 pandemic, since the main blow falls on older people (Polidori et al,. 2021), when the cause of death is not only the virus itself, but also its complications. Let us consider further for what main groups of causes there was an increase in mortality (Table 5, Figure 6).

\section{Table 5. The number of deaths by main classes and individual death causes per year}

\begin{tabular}{|c|c|c|c|c|c|c|c|c|c|c|}
\hline & $\mathbf{2 0 1 1}$ & $\mathbf{2 0 1 2}$ & $\mathbf{2 0 1 3}$ & $\mathbf{2 0 1 4}$ & $\mathbf{2 0 1 5}$ & $\mathbf{2 0 1 6}$ & $\mathbf{2 0 1 7}$ & $\mathbf{2 0 1 8}$ & $\mathbf{2 0 1 9}$ & $\mathbf{2 0 2 0}$ \\
\hline $\begin{array}{c}\text { Infectious and } \\
\text { parasitic diseases }\end{array}$ & 33672 & 32084 & 31808 & 32103 & 34372 & 35335 & 35045 & 34626 & 32918 & 30173 \\
\hline $\begin{array}{c}\text { Coronary heart } \\
\text { disease }\end{array}$ & 568182 & 562957 & 529824 & 492303 & 494638 & 481780 & 461786 & 453306 & 442328 & 508657 \\
\hline $\begin{array}{c}\text { Cerebrovascular } \\
\text { diseases }\end{array}$ & 332804 & 323003 & 310531 & 295602 & 290300 & 279818 & 264468 & 263573 & 260594 & 278618 \\
\hline $\begin{array}{c}\text { Respiratory } \\
\text { diseases }\end{array}$ & 74219 & 70793 & 74068 & 78312 & 75813 & 70332 & 62032 & 61150 & 59188 & 96539 \\
\hline $\begin{array}{c}\text { Diseases of the } \\
\text { digestive system }\end{array}$ & 88910 & 88867 & 88431 & 96689 & 101956 & 98215 & 92989 & 95430 & 98271 & 107399 \\
\hline External causes & 199358 & 193774 & 185353 & 186779 & 177590 & 167543 & 152741 & 144612 & 137633 & 139583 \\
\hline $\begin{array}{c}\text { Alcohol } \\
\text { poisoning }\end{array}$ & 16288 & 15226 & 14549 & 15400 & 15242 & 14021 & 12276 & 11045 & 9876 & 10206 \\
\hline Suicide & 31144 & 29735 & 28779 & 26606 & 25476 & 23119 & 20278 & 18206 & 17192 & 16546 \\
\hline
\end{tabular}




\begin{tabular}{|c|c|c|c|c|c|c|c|c|c|c|}
\hline Murder & 16795 & 15408 & 14427 & 12921 & 11984 & 10569 & 9048 & 7986 & 7302 & 6859 \\
\hline $\begin{array}{c}\text { Malignant } \\
\text { neoplasms }\end{array}$ & 289535 & 287789 & 288636 & 286900 & 296476 & 295729 & 290662 & 293704 & 294400 & 291461 \\
\hline Blastemas & 292445 & 290880 & 291775 & 290400 & 300232 & 299652 & 294587 & 297996 & 298699 & 295910 \\
\hline $\begin{array}{c}\text { Circulatory } \\
\text { diseases }\end{array}$ & 1076458 & 1055592 & 1001799 & 940489 & 930102 & 904055 & 862895 & 856127 & 841207 & 938536 \\
\hline $\begin{array}{c}\text { All types of } \\
\text { transport } \\
\text { accidents }\end{array}$ & 29658 & 30203 & 29191 & 28829 & 24821 & 21610 & 20161 & 19092 & 17787 & 17041 \\
\hline
\end{tabular}

Source: Federal State Statistics Service of Russia, 2021.

Based on the data in Table 5 and Figure 6, by groups of causes of death such as infectious and parasitic diseases, diseases of the digestive system, external causes, cases of alcohol poisoning, suicide, murder, malignant neoplasms, blastema's, all types of transport accidents, the change in mortality occurred within the established trends, and the calculations carried out confirmed this hypothesis. However, according to the groups of causes of death such as coronary heart disease, cerebrovascular diseases, respiratory diseases, diseases of the circulatory system, the situation is radically different. There is an abnormal increase in mortality for these reasons.

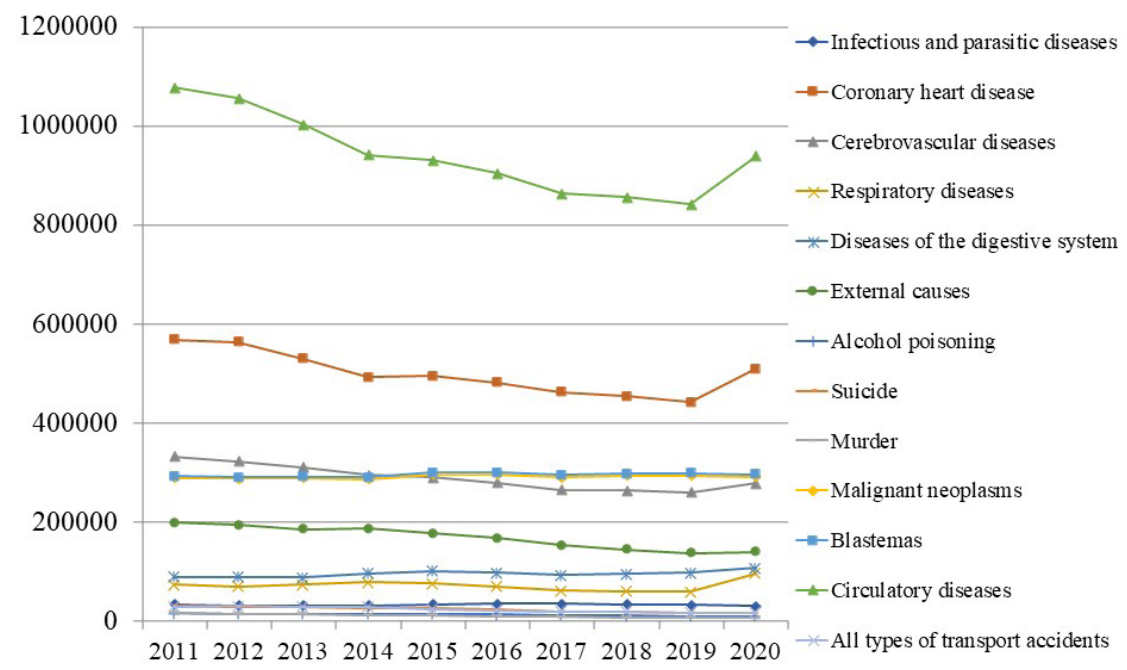

\section{Figure 6. The number of deaths by main classes and} individual death causes per year

Source: Federal State Statistics Service of Russia, 2021. 
Ilmir Nusratullin, Igor Drozdov, Alexei Ermakov, Elena Koksharova y Maya Mashchenko

1000

Natural population movement and COVID-19: data from Russia

To calculate the "excess mortality" due to the indicated reasons in 2020, we will build reliable mortality rate models based on the data of 2011-2019 (Table 7). To do this, we will build polynomial models of the first degree, or simply linear models.

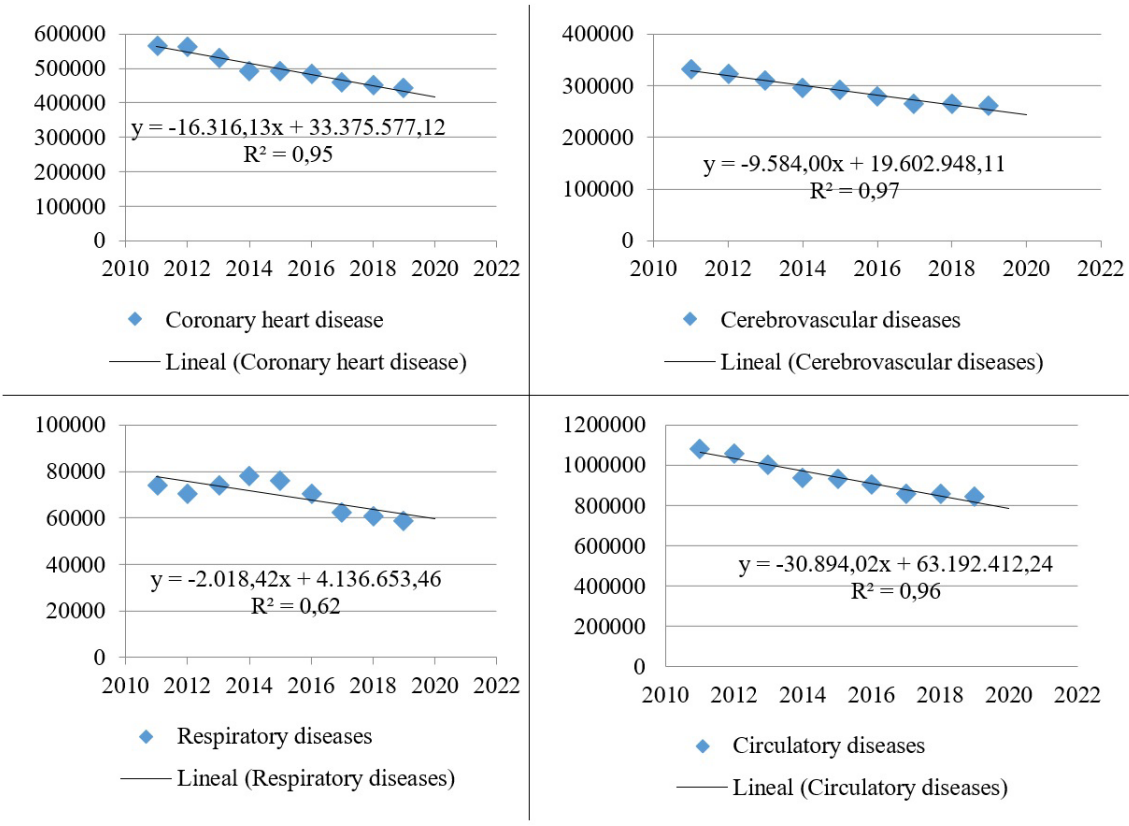

Figure 7. Polynomial models of the first degree of mortality in Russia by their causes according to 2011-2019 data

Source: calculated by the authors.

Based on the models obtained in Figure 7, we will calculate the predicted values of mortality by cause and find the number of "excess deaths" (Table $6)$.

Table 6. The number of "excess deaths" due to their causes in 2020.

\begin{tabular}{|c|c|c|c|}
\hline & $\begin{array}{c}2 \mathrm{2O20} \\
\text { (actual } \\
\text { facts) }\end{array}$ & $\begin{array}{c}2 \mathrm{O} 20 \\
\text { (prognosis) }\end{array}$ & $\begin{array}{c}\text { The number of } \\
\text { "excess deaths" due } \\
\text { to their causes }\end{array}$ \\
\hline Coronary heart disease & 508657 & 416995 & 91662 \\
\hline
\end{tabular}




\begin{tabular}{|c|c|c|c|}
\hline Cerebrovascular diseases & 278618 & 243268 & 35350 \\
\hline Respiratory diseases & 96539 & 59445, & 37094 \\
\hline Circulatory diseases & 938536 & 786492 & 152044 \\
\hline Total & $\mathrm{x}$ & $\mathrm{x}$ & 316150 \\
\hline
\end{tabular}

Thus, in 2020, there were 91,662 "excess deaths" due to coronary heart disease, 35,350 - due to cerebrovascular diseases, 37,094 - due to respiratory diseases, 152,044 - due to diseases of the circulatory system, and total 316,150 "excess deaths". These data also indirectly indicate that they are associated with the COVID-19 pandemic, since the main complications in COVID-19 disease are these reasons (Polidori et al., 2021).

Again, the results obtained are in no way comparable with the official data, according to which 59,019 people died from COVID-19 in Russia in 2020 (Starostina and Tkachev, 2021). They are more comparable with the results we obtained earlier, namely, 386,813 "excess deaths".

Our data on the real number of deaths in Russia from COVID-19 is also comparable with the findings of other scientists. The Ryazantsev et al. (2021) study also noted the excess mortality in the amount of 324,000 people in Russia in 2020. According to the authors, more than a third of these losses are associated with coronavirus infection, directly or indirectly. The Lifshits and Neklyudova (2020) econometric analysis showed that in Russia the real mortality rates were underestimated by more than 2 times, and as new data became available, the results were confirmed.

According to Lifshits and Neklyudova (2020) real indicators began to be underestimated in May 2020, both in the number of cases and in the number of deaths. Kobak (2021) argues that data on additional deaths in Russia in 2020 paint a much darker picture of the death toll from Covid-19 than the official daily updated figures. Analysis of excess mortality in Russia from April to November yielded a dismal 264,100 additional deaths from COVID-19 in Russia.

It should be noted that at the beginning of 2021 Federal State Statistics Service of Russia published statistics according to which the number of deaths from COVID-19 itself was 57,019, deaths associated with the consequences of COVID-19 amounted to 103,968 deaths, which totally works out 162,249 deaths (Starostina and Tkachev, 2021). However, these data are also not comparable with the results obtained by us and other scientists. 
Ilmir Nusratullin, Igor Drozdov, Alexei Ermakov, Elena Koksharova y Maya Mashchenko
1002 Natural population movement and COVID-19: data from Russia

\section{Conclusions}

The natural population movement in Russia over the past 10 years has a negative trend and can be characterised as depopulation. The total fertility rate in Russia from 2011 to 2015 grew steadily from 1.58 to 1.78 , but since 2016 it has seen a sharp drop to 1.51 in 2020. From 2011 to 2015, there is a clear trend towards an increase in the number of births from 1.80 million to 1.94 million, but in 2016 this trend is reversed and in 2020 the number of births was 1.44 million. As for the number of deaths, its trend is clearer and there is a gradual decrease in mortality from 1.93 million to 1.80 million in 2019 , but only in 2020, there is a sharp spike to 2.14 million.

According to official data, the number of deaths from COVID-19 itself was 57,019 deaths, and those associated with the consequences of COVID-19 are 103,968 deaths, which is a total of 162,249 deaths. Within the framework of our study, from 316,150 to 386,813 "excess deaths" from COVID-19 were identified by constructing predictive models of mortality in general and for their reasons. Thus, an underestimation of the official mortality rate from COVID-19 was revealed from 2.4 to 6.8 times, depending on the data source.

A sharp spike in mortality in Russia in 2020 occurred among people over 50 , and, with increasing age, mortality increased. The main reasons for the sharp increase in mortality were coronary heart disease, cerebrovascular diseases, respiratory diseases, and diseases of the circulatory systems. Understanding the true catastrophe of COVID-19 in Russia will allow us to critically evaluate the actions of state and municipal authorities, as well as draw the right conclusions on how to get out of this catastrophic situation.

\section{Bibliographic references}

ADENIYI, Michael; EKUM, Matthew; ILUNO, C; OGUNSANYA, A; AKINYEMI, J; OKE, S; MATADI, M. 2020. "Dynamic Model of COVID-19 disease with exploratory data analysis" In: Scientific African. Vol. 9. No. 14, pp. 166-182.

AL-RAEEI, Marwan. 2020. "Te forecasting of COVID-19 with mortality using SIRD epidemic model for the United States, Russia, China, and the Syrian Arab Republic" In: AIP Advances. Vol. 10, No. 6, pp. 70-82.

ANASTASSOPOULOU, Cleo; RUSSO, Lucia; TSAKRIS, Athanasios; SIETTOS, Constantinos. 2020. "Data-based analysis, modelling and forecasting of the COVID-19 outbreak" In: Plos One. Vol. 15, No. 3, pp. 114-123. 
ARE, Stephen Olusegun; EKUM, Matthew Iwada. 2020. "COVID-19 pandemic data visualization with moment about midpoint: exploratory and expository analyses" In: Asian Journal Probability Statistics. Vol. 8, No. 4, pp. 15-37.

ARONOV, Iosif; MAKSIMOVA, Olga; GALKINA, Nataliia. 2020. "COVID-19 Highest Incidence Forecast in Russia Based on Regression Model" In: International Journal of Mathematical Engineering and Management Sciences. Vol. 5, No. 5, pp. 812-819.

BOLLINGER, Robert; RAY, Stuart. 2021. New Variants of Coronavirus: What You Should Know. Johns Hopkins Medicine. Available online. In: https://www.hopkinsmedicine.org/health/conditions-and-diseases/ coronavirus/a-new-strain-of-coronavirus-what-you-should-know. Date of consultation: 05/05/2021.

CHINTALAPUDI, Nalini; BATTINENI, Gopi; AMENTA, Francesco. 2020. "COVID-19 virus outbreak forecasting of registered and recovered cases after sixty day lockdown in Italy: A data driven model approach" In: Journal of Microbiology Immunology and Infection. Vol. 53, No. 3, pp. 396-403.

CHUDIK, Alexander; MOHADDES, Kamiar; PESARAN, Hashem; RAISSI, Mehdi; REBUCCI, Alessandro. 2020. Economic consequencies of COVID-19: A counterfactual multi-country analysis. Research-based policy analysis and commentary from leading economists. Available online. In: https://voxeu.org/article/economic-consequences-covid-19multi-country-analysis. Date of consultation: 05/05/2021.

DRAPKINA, Oksana; SAMORODSKAYA, Irina; SIVTSEVA, Marina; KAKORINA, Ekaterina; BRIKO, Nikolay; CHERKASOV, Sergey; ZINSERLING, Vsevolod; MALKOV, Pavel. 2020. "COVID-19: urgent questions for estimating morbidity, prevalence, case fatality rate and mortality rate" In: Cardiovascular Terapy and Prevention. Vol. 19, No. 3, article №2585.

FEDERAL STATE STATISTICS SERVICE OF RUSSIA. 2021. Statistical Dashboard. Available online. In: https://showdata.gks.ru/finder/. Date of consultation: 05/05/2021.

FERGUSON, Neil; LAYDON, Daniel; NEDJATI-GILANI, Gemma; IMAI, Natsuko; AINSLIE, Kylie. 2020. Impact of non-pharmaceutical interventions (NPIs) to reduce COVID-19 mortality and healthcare demand. Imperial College COVID-19 Response Team. Available online. In: https://www.imperial.ac.uk/mrc-global-infectious-disease-analysis/ covid-19/report-9-impact-of-npis-on-covid-19/. Date of consultation: 05/05/2021. 
Ilmir Nusratullin, Igor Drozdov, Alexei Ermakov, Elena Koksharova y Maya Mashchenko

1004

Natural population movement and COVID-19: data from Russia

FERRARO, Ottavia Eleonora; PUCI, Mariangela Valentina; MONTOMOLI, Cristina; ROLESU, Sandro; CAPPAI, Stefano; LOI, Federica. 2020. "Official Data and Analytical Forecasts: Diferences and Similarities Among Coronavirus Disease (COVID-19)" In: Frontiers in Medicine. No. 7, No. 239, pp. 363-382.

GAO, Yuanyuan; ZHANG, Zuqin; YAO, Wei; YING, Qi; LONG, Chen; FU, Xinmiao. 2020. "Forecasting the cumulative number of COVID-19 deaths in China: a Boltzmann function-based modeling study" In: Infection Control and Hospital Epidemiology. Vol. 41, No. 7, pp. 841-843.

GERLI, Alberto; CENTANNI, Stefano; MIOZZO, Monica; VIRCHOW, Chistian; SOTGIU, Giovanni; CANONICA, Walter; SORIANO, Joan. 2020. "COVID-19 mortality rates in the European Union, Switzerland, and the UK: effect of timeliness, lockdown rigidity, and population density" In: Minerva medica. Vol. 111, No. 4, pp. 308-314.

HUANG, Chaolin; WANG, Yemin; LI, Xingwang; REN, Lili; ZHAO, Jianping; HU, Yi. 2020. "Clinical features of patients infected with 2019 novel coronavirus in Wuhan, China” In: The Lancet. Vol. 395, No. 10223, pp. 497-506.

ILUNO, Christiana; TAYLOR, Jimoh; AKINMOLADUN, Olusegun; ADERELE, Oluwaseun; EKUM, Matthew. 2021. "Modelling the effect of Covid-19 mortality on the economy of Nigeria" In: Research in Globalization. Vol. 3, No. 100050, pp. 1200-1242.

IVANAJ, Ernest; OUKHALLOU, Youssef. 2020. The Economic and Institutional Determinants of COVID-19 Mortality. Munich Personal RePEc Archive. Available online. In: https://mpra.ub.uni-muenchen.de/103895/. Date of consultation: 05/05/2021.

KOBAK, Dmitry. 2021. "Excess mortality reveals Covid's true toll in Russia" Significance. Vol. 18, No. 1, pp. 16-19.

LI, Qun; GUAN, Xuhua; WU, Peng; WANG, Xiaoye; ZHOU, Lei; TONG, Yeqing. 2020. "Early transmission dynamics in Wuhan, China, of novel coronavirus-infected pneumonia" In: The New England Journal of Medicine. No. 382, pp. 1199-1207.

LIFSHITS, Marina; NEKLYUDOVA, Natalia. 2020. "COVID-19 mortality rate in Russian regions: forecasts and reality” In: R-economy. Vol. 6, No. 3, pp. 171-182.

LIU, Yin; GAYLE, Albert A; WILDER-SMITH, Annelies; ROCKLÖV, Joacim. 2020. "The reproductive number of COVID-19 is higher compared to SARS coronavirus" In: Journal of Travel Medicine. Vol. 27, No. 2, pp. 06-19. 
MIDDELBURG, Rutger A; ROSENDAAL, Frits. 2020. "COVID-19: How to make between-country comparisons" In: International Journal of Infectious Diseases. Vol. 96, pp. 477-481.

NUSRATULLIN, Ilmir; KUZNETSOVA, Svetlana; GAZIZYANOVA, Yuliya; KUTSENKO, Ekaterina; BEREZHNAYA, Lubov. 2020. "Socio-economic development of Russia in terms of the BRICS countries' development" In: Amazonia Investiga. Vol. 9, No. 27, pp. 52-61.

NUSRATULLIN, Ilmir; MROCHKOVSKIY, Nikolay; YARULLIN, Raul; ZAMYATINA, Natalia; SOLNTSEVA, Oksana. 2021. The "Financial Implications of the Coronavirus COVID-19 Pandemic: A Review" In: Cuestiones Politicas. Vol. 39, No. 68, pp. 325-342.

ONDER, Graziano; REZZA, Giovanni; BRUSAFERRO, Silvio. 2020. "CaseFatality Rate and Characteristics of Patients Dying in Relation to COVID-19 in Italy" In: Jama-Journal of the American Medical Association. Vol. 323, No. 18, pp. 1775-1776.

ORAN, Daniel; TOPOL, Eric. 2020. "Prevalence of Asymptomatic SARS-CoV-2 Infection: A Narrative Review” In: Annals of internal medicine. Vol. 173, No. 5, pp. 362-367.

POLIDORI, Cristina; SIES, Helmut; FERRUCCI, Luigi; BENZING, Thomas. 2021. "COVID-19 mortality as a fingerprint of biological age" In: Ageing Research Reviews. Vol. 67, article №101308.

READ, Jonathan; BRIDGEN, Jessica; CUMMINGS, Derek; HO, Antonio; JEWELL, Chirs. 2021. "Novel coronavirus 2019-nCoV (COVID-19): early estimation of epidemiological parameters and epidemic size estimates" In: Philosophical Transactions B. Vol. 376, No. 20200265.

RYAZANTSEV, Sergey; IVANOVA, Alla; ARKHANGELSKY, Vladimir. 2021. "Increasing Depopulation in Russia in the Context of the Covid-19 Pandemic: Regional Features" In: Bulletin of the South-Russian State Technical University (NPI) Series Socio-Economic Sciences. Vol. 14, No. 2, pp. 7-20.

SÁNCHEZ-VILLEGAS, Pablo; CODINA, Antonio Daponte. 2020. "Modelos predictivos de la epidemia de COVID-19 en España con curvas de Gompertz. Gaceta Sanitaria” In: Press. Vol. 35, No. 6, pp. 263-290.

SEBASTIANI, Giovanny; MASSA, Marco; RIBOLI, Elio. 2020. "Covid-19 epidemic in Italy: evolution, projections and impact of government measures" In: European Journal of Epidemiology. Vol. 4, No. 35, pp. 341-345. 
Ilmir Nusratullin, Igor Drozdov, Alexei Ermakov, Elena Koksharova y Maya Mashchenko
1006 Natural population movement and COVID-19: data from Russia

SEMENOVA, Yuliya; GLUSHKOVA, Natalya; PIVINA, Lyudmila; KHISMETOVA, Zaituna; ZHUNUSSOV, Yersin; SANDYBAEV, Marat; IVANKOV, Alexandr. 2020. "Epidemiological Characteristics and Forecast of COVID-19 Outbreak in the Republic of Kazakhstan" In: Journal of Korean Medical Science. Vol. 35, No. 24, pp. 45-56.

SHOJAEE, Sajad; POURHOSEINGHOLI, Mohamad Amin; ASHTARI, Sara; VAHEDIAN-AZIMI, Amir; ASADZADEH-AGHDAEI, Hamid; ZALI, Mohammad Reza. 2020. "Predicting the mortality due to Covid-19 by the next month for Italy, Iran and South Korea; a simulation study" In: Gastroenterology and hepatology from bed to bench. Vol. 13, No. 2. pp 177-179.

SORNETTE, Didier; MEARNS, Euan; SCHATZ, Michael; WU, Ke; DARCET, Didier. 2020. Interpreting, analysing and modelling COVID-19 mortality data. Nonlinear dynamics, 1-26. Available online. In: https://doi. org/10.1007/s11071-020-05966-z. Date of consultation: 05/05/2021.

STAROSTINA, Julia; TKACHEV, Ivan. 2021. Rosstat named the number of deceased Russians with COVID-19 in 2020. Available online. In: https:// www.rbc.ru/economics/o8/02/2021/602132e19a7947073f7ddeb5. Date of consultation: 05/05/2021.

TANG, Biao; WANG, Xia; LI, Qian; BRAGAZZI, Nicola Luigi; TANG, Sanyi; XIAO, Yanni; WU, Jianhong. 2020. "Estimation of the Transmission Risk of the 2019-nCoV and Its Implication for Public Health Interventions" In: Journal of clinical medicine. Vol. 9, No. 2, pp. 462-479.

UNITED NATIONS. 2020. World Economic Situation and Prospects 2021. Available online. In: https://www.un.org/development/desa/dpad/ publication/world-economic-situation-and-prospects-2021/. Date of consultation: 05/05/2021.

VANDOROS, Sotiris. 2020. "Excess mortality during the Covid-19 pandemic: Early evidence from England and Wales" In: Social Science \& Medicine. Vol. 258, article № 113101.

WORLD HEALTH ORGANIZATION. 2021. WHO Coronavirus (COVID-19) Dashboard. Available online. In: https://covid19.who.int/. Date of consultation: 05/05/2021.

WU, Zunyou; MCGOOGAN, Jennifer. 2020. "Characteristics of and Important Lessons From the Coronavirus Disease 2019 (COVID-19) Outbreak in China: Summary of a Report of 72314 Cases From the Chinese Center for Disease Control and Prevention" In: JAMA. Vol. 13, No. 323, pp. 1239-1242. 
YANG, Shu; CAO, Peihua; DU, Peipei; WU, Ziting; ZHUANG, Zian; YANG, Lin; YU, Xuan; ZHOU, Qi; FENG, Xixi; WANG, Xiaohui; LI, Weiguo; LIU, Enmei; CHEN, Ju; CHEN, Yaolong; HE, Daihai. 2020. "Early estimation of the case fatality rate of COVID-19 in mainland China: a data-driven analysis" In: Annals of translational medicine. Vol. 8, No. 4, pp. 128-140.

ZHAO, Shi; LIN, Qianyi; RAN, Jinjun; MUSA, Sahilu; YANG, Guangpu; WANG, Weiming; LOU, Yijun; GAO, Daoz; YANG, Lin; HE, Daihai; WANG, Maggie. 2020. "Preliminary estimation of the basic reproduction number of novel coronavirus (2019-nCoV) in China, from 2019 to 2020: A data-driven analysis in the early phase of the outbreak" In: International journal of infectious diseases: IJID: official publication of the International Society for Infectious Diseases. No. 92. pp 214-217. 

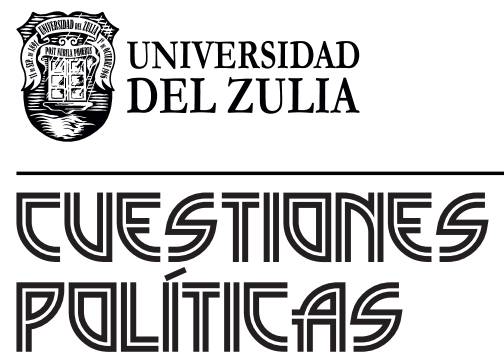

Vol. 39 N $^{\circ} 71$

Esta revista fue editada en formato digital y publicada en diciembre de 2021, por el Fondo Editorial Serbiluz, Universidad del Zulia. Maracaibo-Venezuela 